\title{
Evolutionary history of the seagrass genus Posidonia
}

\author{
Tânia Aires ${ }^{1}$, Núria Marbà ${ }^{2}$, Regina L. Cunha ${ }^{1}$, Gary A. Kendrick ${ }^{3}$, Diana I. Walker ${ }^{3}$, \\ Ester A. Serrão ${ }^{1}$, Carlos M. Duarte ${ }^{2}$, Sophie Arnaud-Haond ${ }^{1,4, *}$ \\ ${ }^{1}$ CCMAR-CIMAR, Center for Marine Sciences, University of Algarve, Gambelas, 8005-139 Faro, Portugal \\ ${ }^{2}$ Department of Global Change Research, IMEDEA (CSIC-UIB) Institut Mediterráni d'Estudis Avançats, Miquel Marques 21, \\ 07190 Esporles, Mallorca, Spain \\ ${ }^{3}$ School of Plant Biology, The University of Western Australia, Crawley 6009, Australia \\ ${ }^{4}$ IFREMER- Technopole de Brest-Iroise, BP 70, 29280 Plouzané, France
}

\begin{abstract}
Seagrasses are the structural species of one of the most important coastal ecosystems worldwide and support high levels of biodiversity and biomass production. Posidonia is one of the most ancient seagrass genera and displays a contrasting disjunct biogeographic pattern. It contains one single species in the Northern Hemisphere, $P$. oceanica, which is endemic to the Mediterranean Sea, and has up to 8 recognized taxa in the Southern Hemisphere, which in Australia are divided into 2 complexes, $P$. ostenfeldii and $P$. australis. A phylogeny based on a nuclear marker (rRNA-ITS) revealed an ancient split between the northern (i.e. Mediterranean) and southern (i.e. Australian) taxa, followed by a separation of the 2 recognized Australian complexes. However, the species belonging to the $P$. ostenfeldii complex were indistinguishable, suggesting an ecotypic origin or a recent speciation. Therefore, among the 7 morphologically described Australian species only 4 species lineages can be discriminated. The organelle markers nad7 intron, trnL-F and matK/trnK intron were not informative for reconstructing the phylogeny of this genus, and the mitochondrial markers exhibited a strikingly slow evolutionary rate relative to other genome regions.
\end{abstract}

KEY WORDS: Posidonia · Phylogeny · Low evolutionary rates · Ancient diversification

\section{INTRODUCTION}

Seagrasses are clonal angiosperms that adapted to life in the sea where they form important habitat structures and enhance biodiversity and primary production in coastal ecosystems (Hemminga \& Duarte 2000). Seagrasses colonized the sea about 100 million years ago (Hemminga \& Duarte 2000) and presently comprise only about 60 species. They represent less than $0.02 \%$ of the angiosperm flora (Les et al. 1997) and are distributed in 5 monocotyledon families (Cronquist 1988, Cook 1990) containing 12 genera. This consistent paucity in the number of species has been attributed to several factors, including the large-scale dispersal that is facilitated by the lack of barriers (Palumbi 1994, Vermeij 1987) in the marine realm, and the uniform marine environment (Hemminga \& Duarte 2000, Darling et al. 2004), the lack of co-evolution with pollinators associated with the adaptation to pollination in aquatic environments (van der Hage 1996, Ollerton \& McCollin 1998, Raven 1998), lack of competition (e.g. Losos 2000) and dominance of clonal growth (Waycott et al. 2006). Yet, genetic studies in populations of Cymodocea nodosa, Posidonia oceanica, Zostera noltii and $Z$. marina have reported high differentiation along their distributional ranges, although species- and site-dependent (Coyer et al. 2004, Olsen et al. 2004, Arnaud-Haond et al. 2007, Alberto et al. 2008). This indicates that large-scale dispersal as a general rule does not occur for seagrasses; therefore, unusual patterns of molecular evolution may have occurred and should be explored.

Species of the genus Posidonia are the only members of the seagrass family Posidoniaceae and are considered to rank among the earliest marine angiosperms 
(Den Hartog 1970). Fossils of Posidonia found in Europe and recorded from the Cretaceous to the Miocene have remained apparently almost unchanged over this long evolutionary history (Den Hartog 1970).

Based on ecological, vegetative, reproductive and morphological characteristics, 9 species were initially described with a unique fragmented distribution. Posidonia oceanica is endemic to the Mediterranean Sea, whereas the other 8 described species ( $P$. australis, $P$. sinuosa and $P$. angustifolia from the $P$. australis complex and $P$. coriacea, $P$. denhartogii, $P$. kirkmanii, $P$. ostenfeldii and $P$. robertsoniae from the $P$. ostenfeldii complex) are restricted to subtropical and temperate Australian waters (Cambridge \& Kuo 1979, Kuo \& Cambridge 1984) and are separated by about $17000 \mathrm{~km}$ from their Mediterranean congeneric species. More recently, morphological information combined with allozymes revealed that $P$. coriacea and $P$. robertsoniae within the $P$. ostenfeldii complex are synonyms (Campey et al. 2000) resulting in 7 recognized species in the Australian complexes. Despite the relatively small number of Posidonia species, 3 groups are recognized based on the presence or absence of a primary root in the Australian and Mediterranean species respectively, on the width of their leaf (thicker but stiffer in the P. ostenfeldii complex) and on rhizome features (horizontal/vertical growth) as well as ecological characteristics associated with the 2 Australian groups ( $P$. australis and $P$. ostenfeldii complexes) (Gobert et al. 2006).

Australian species of Posidonia are distributed along the southwestern, southern and southeastern coasts of Australia (Box 1). P. oceanica covers an area in the Mediterranean Sea between 2.5 and 5 million ha (Pasqualini et al. 1998). Previous genetic analyses (Waycott \& Les 2000) and the fossil record have shown one Australian ( $P$. australis) and one Mediterranean $(P$. oceanica) species to be genetically distant, which support an early evolutionary separation (Gobert et al. 2006). Based on presumed geological history and continental drift, Phillips \& Menez (1988) estimated that the Australian $P$. australis and the Mediterranean $P$. oceanica diverged during the late Eocene ca. 40 million years before present (Myr BP). However, using a molecular clock based on internal transcribed spacer (ITS) and $r b c L$ markers, Les et al. (2003) estimated a more recent divergence $(16.7 \pm 12.3 \mathrm{Myr} \mathrm{BP})$. The Tethys Sea closure during the Miocene is thought to have played an important role in the disjunction of Mediterranean and Australian taxa (Searle et al. 1987, Robertson \& Comas 1998). Besides this comparison, preliminary results for Posidonia phylogeny on the basis of partial ITS and chloroplastidial sequences (Waycott \& Les 2000, Waycott et al. 2006) showed no differences among species within the P. ostenfeldii complex, but had low support for Australian taxa. In the absence of details about the markers used, the lack of clear lineage sorting reported among species may be due to the low resolution of markers used or a possible synonymy of some of the morphologically defined taxa. Further analyses with various markers are therefore still needed to reconstruct a comprehensive phylogeny of the Posidonia genus. This would resolve species boundaries and their biogeographic history as well as clarify the pattern of molecular evolution in the genomes (organelle and nuclear) of these seagrass species.

Here we analyzed the phylogenetic relationship of all 8 morphologically recognized Posidonia species with a comprehensive set of markers from the 3 compartments of the genome (nuclear, mitochondrial and chloroplastidial). Our aim was to (1) help resolve the taxonomic status of the Australian species because some morphological characters used to determine species remain under debate and (2) compare the phylogenetic patterns observed with various markers from both organelle (chloroplastidial and mitochondrial) and nuclear genomes. After screening various loci for variability and phylogenetic information content to resolve the phylogeny of Posidonia, mitochondrial (nad 7 intron), chloroplastidial (trnL-F and matK/trnK intron) and nuclear (ITS) markers were retained.

\section{MATERIALS AND METHODS}

Plant material, markers amplification and sequencing. We followed the methods described by Campey et al. (2000) to investigate 7 distinct Australian species in this study. Sampling of Posidonia in Australia and in the Mediterranean Sea was performed in 2002; DNA was extracted by means of the $1 \% \mathrm{~N}$-cetyl N,N,Ntrimethylammonium bromide (CTAB) method (Doyle \& Doyle 1987) and stored at $-20^{\circ} \mathrm{C}$. Sampling sites and number of individuals per species analyzed in this study are described in Table 1. Several individuals of each of the following species were collected: $P$. australis, $P$. angustifolia, $P$. sinuosa, $P$. coriacea, $P$. denhartogii, $P$. kirkmanii and $P$. oceanica (the latter from geographically distant sites within the Mediterranean, i.e. Spain, Italy, Cyprus, Greece, Malta and Tunisia). In total, 31 individuals were collected. All Australian taxa were identified in the field. An outgroup taxon, Ruppia cirrhosa, was selected based on phylogenetic distance from the ingroup (Les et al. 1997).

Mitochondrial regions: Mitochondrial coding sequences of Posidonia species available in GenBank (apocytochrome b [cob], accession nos. DQ8591498 and DQ859149; ATPase [atp1], accession nos. DQ85 9111 and DQ859112) were aligned and analyzed to 
Box 1. Distribution, habitat preference and taxonomy of Australian Posidonia species

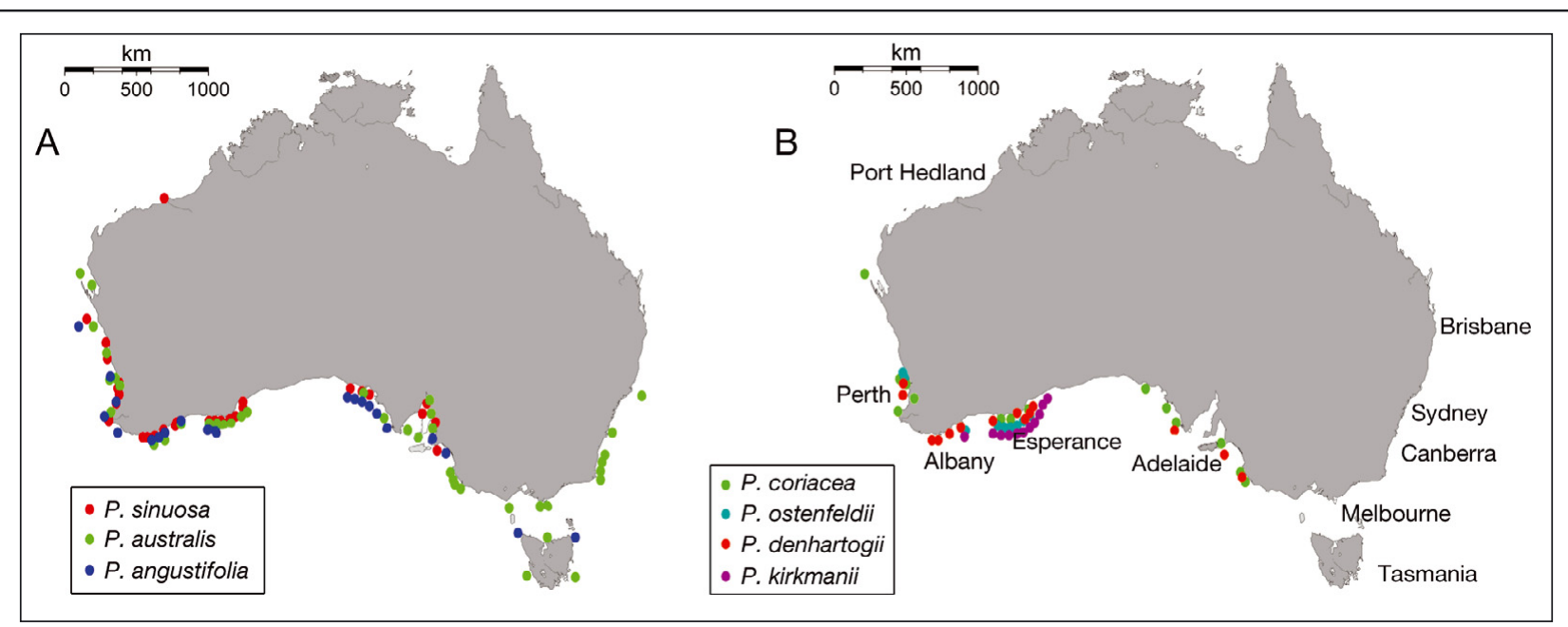

Fig. B1. Distribution of Posidonia species around Australia

Distribution: The complex Posidonia australis is composed of $P$. australis, $P$. sinuosa and $P$. angustifolia (all previously described as ' $P$. australis') (Cambridge \& Kuo 1979). The species that gives the name to this complex has the widest distribution among Australian Posidonia species and is found from western Australia (from Shark Bay), around the southern and southeastern coastlines and along the northern coast of Tasmania (Cambridge \& Kuo 1979, Kuo \& Cambridge 1984, Trautman \& Borowitzka 1999 Fig. B1A). P. sinuosa has a similar geographic range in Western Australia (although its northern limit is Port Headland) but does not extend farther east than Kingston in southern Australia (Trautman \& Borowitzka 1999), while $P$. angustifolia is found from the Houtman Abrolhos and along the southwest coast of Western Australia to Encounter Bay, southern Australia (Cambridge \& Kuo 1979). P. australis and P. sinuosa typically inhabit relatively sheltered coastal waters where they are protected from strong currents, whereas $P$. angustifolia is found in more exposed habitats (Kuo \& Cambridge 1984, Carruthers et al. 2007).

Species from the Posidonia ostenfeldii complex are distributed along the coast of southern Australia, and P. coriacea, the most widely distributed of this complex, is also found along the western coast (Fig. B1B). Individuals belonging to the $P$. ostenfeldii complex grow in open waters along the coast and in high energy coastal sublittoral habitats (Kuo \& Cambridge 1984).

Taxonomy: The first species of Posidonia genus to be described was $P$. oceanica Linnaeus, 1735 in Systema Naturae, although the genus was then named Zostera. The genus itself was described by König 70 yr later and then, the former Z. oceanica was renamed by Delile (1813) and included here as $P$. oceanica. In 1858, another species was described and recognized as member of Posidonia genus; it was geographically distant from $P$. oceanica and had different characteristics such has the absence of a primary root. Joseph Hooker and his colleague Thomas Thomson (1858) named it $P$. australis because of its location. Much later, Den Hartog (1970) described a distinct species based on the morphology of the leaves and rhizome, $P$. ostenfeldii.

Within Posidonia australis 2 different forms were recognized, the 'broad leaved' form and the 'narrow leaved' form. The different forms occurred in sympatry and until 1979 were thought to be the same species (Cambridge \& Kuo 1979). A study by Cambridge \& Kuo (1979) recognized differences in the shape of the epidermal cells, the position of fibre cells in the leaf and leaf sheath and the presence around the rhizome of straw-like fibres, which distinguished 2 species that also differed in habitat, growth patterns and depth distribution. The 'broad leaved' form is now formally recognized as $P$. australis and the 'narrow leaved form' is now called $P$. angustifolia. A third 'narrow leaved' species was previously included in $P$. angustifolia or in P. ostenfeldii but is now known as P. sinuosa (Cambridge \& Kuo 1979).

The Australian Posidonia ostenfeldii, which has thicker and stiffer leaves than its congeneric $P$. australis, was redescribed in 1984 by John Kuo and Marion Cambridge (Kuo \& Cambridge 1984). As for the other Australian group, taxonomists felt the different morphologic forms could actually be different species. This group of species inhabits more exposed waters with stronger wave action (Kuo \& Cambridge 1984). They considered leaf morphology and anatomy - a combination of the leaf width (that can sometimes overlap), number of vascular bundles, the appearance of epidermal cells in surface view and in cross-section and fibre bundles in the leaf sheaths - as the best characteristics for distinguishing the species (Kuo \& Cambridge 1984). From this reanalysis 4 additional new species were added to the Posidonia genus as we know it today: $P$. denhartogii, $P$. robertsoniae, $P$. coriacea and $P$. kirkmanii. A further study by (Campey et al. 2000) aimed at re-evaluating species boundaries among this complex suggested that all these species actually are synonymous. The morphologic features analyzed did not separate the species into distinct groups, suggesting a morphological continuum. In addition, no polymorphism was detected with allozymes among all taxa. When comparing $P$. robertsoniae and $P$. coriacea, those authors suggested that differences between those 2 species are largely the result of environmental and developmental factors and there is little evidence to support 2 different species (Spalding et al. 2003). The whole P. ostenfeldii complex was questioned until further morphological and genetic evidence could resolve their status. 
Table 1. Posidonia taxa included in this study with sampling location and markers used. Also shown is Ruppia cirhosa, used as the outgroup in the analysis

\begin{tabular}{|c|c|c|}
\hline Species & Locality & Markers amplified in this study \\
\hline P. kirkmanii Kuo and Cambridge & Western Australia, Wylie Bay & ITS, nad7, trnL \\
\hline P. kirkmanii Kuo and Cambridge & Western Australia, Wylie Bay & $\begin{array}{l}\text { ITS, } \operatorname{trnL}, \text { matK/trnK intron, } \\
\text { trnL-F }\end{array}$ \\
\hline P. ostenfeldii den Hartog & Western Australia, Wylie Head & ITS, nad 7, $\operatorname{trnL}, \operatorname{trnL}-\mathrm{F}$ \\
\hline P. ostenfeldii den Hartog & Western Australia, Wylie Head & ITS, $\operatorname{trnL}$ \\
\hline P. ostenfeldii den Hartog & Western Australia, Wylie Head & ITS, $\operatorname{trnL}$ \\
\hline P. sinuosa Cambridge and Kuo & Western Australia, Lal Bank & ITS, nad7, trnL, trnL-F \\
\hline P. sinuosa Cambridge and Kuo & Western Australia, Two Peoples Bay & ITS, $\operatorname{trnL}$ \\
\hline P. sinuosa Cambridge and Kuo & Western Australia, Wanbro Sound & ITS, $\operatorname{trnL}$ \\
\hline P. sinuosa Cambridge and Kuo & Western Australia, Duke of Orleans Bay & ITS, $\operatorname{trnL}$ \\
\hline P. sinuosa Cambridge and Kuo & Western Australia, Duke of Orleans Bay & ITS, $\operatorname{trnL}$ \\
\hline$P$. australis Hook. f. & Western Australia, Lal Bank & ITS, nad7, trnL \\
\hline P. australis Hook. f. & Western Australia, Duke of Orleans Bay & ITS, $\operatorname{trnL}$ \\
\hline P. australis Hook. f. & Western Australia, Wanbro Sound & ITS, $\operatorname{trnL}$ \\
\hline P. australis Hook. f. & Western Australia, Wanbro Sound & ITS, $\operatorname{trnL}$ \\
\hline P. australis Hook. f. & Western Australia, Two Peoples Bay & ITS, trnL \\
\hline P. australis Hook. f. & Western Australia, Duke of Orleans Bay & ITS, trnL \\
\hline$P$. australis Hook. $\mathrm{f}$. & Western Australia, Duke of Orleans Bay & ITS, $\operatorname{trnL}$ \\
\hline P. angustifolia Cambridge and Kuo & Western Australia, Lal Bank & ITS, $\operatorname{nad} 7, \operatorname{trnL}$ \\
\hline P. angustifolia Cambridge and Kuo & Western Australia, Lal Bank & ITS, $\operatorname{trnL}$ \\
\hline P. coriacea Cambridge and Kuo & Western Australia, Taylor St Jetty & ITS, $\operatorname{nad} 7$ \\
\hline P. coriacea Cambridge and Kuo & Western Australia, Taylor St Jetty & ITS, $\operatorname{trnL}$ \\
\hline P. coriacea Cambridge and Kuo & Western Australia, Success Bank & ITS, $\operatorname{trnL}, \operatorname{trnL}-\mathrm{F}$ \\
\hline$P$. coriacea Cambridge and Kuo & Western Australia, Two Peoples Bay & ITS, $\operatorname{trnL}$ \\
\hline P. coriacea Cambridge and Kuo & Western Australia, Two Peoples Bay & ITS, $\operatorname{trnL}$ \\
\hline P. denhartogii Kuo and Cambridge & Western Australia, Wylie Head & ITS, nad7, trnL \\
\hline P. oceanica (L.) Delile & Spain, Rodalquilar & $\begin{array}{l}\text { ITS, nad } 7, \text { trnL, } \\
\text { matK/trnK intron, trnL-F }\end{array}$ \\
\hline P. oceanica (L.) Delile & North Italy (Camogli), 909.00' E, $44^{\circ} 20.00^{\prime} \mathrm{N}$ & ITS \\
\hline P. oceanica (L.) Delile & Cyprus (Paphos), $32^{\circ} 26.23^{\prime} \mathrm{E}, 34^{\circ} 43.54^{\prime} \mathrm{N}$ & ITS \\
\hline P. oceanica (L.) Delile & Greece (Agios Nicolaos), $23^{\circ} 55.62^{\prime} \mathrm{E}, 37^{\circ} 42.7^{\prime} \mathrm{N}$ & ITS \\
\hline P. oceanica (L.) Delile & Malta, $14^{\circ} 20.00^{\prime} \mathrm{E}, 35^{\circ} 59.00^{\prime} \mathrm{N}$ & ITS \\
\hline P. oceanica (L.) Delile & Tunisia (Ergla), $10^{\circ} 36.00^{\prime} \mathrm{E}, 35^{\circ} 53.00^{\prime} \mathrm{N}$ & ITS \\
\hline Ruppia cirrhosa & & GenBank (AJ012292), ITS \\
\hline
\end{tabular}

obtain a first estimate of their putative usefulness in discriminating species. A pairwise comparison was systematically first performed with $P$. oceanica and one of the Australian representatives ( $P$. australis or P. kirkmanii) to assess the level of polymorphism of each marker. When polymorphism was low between these supposedly most distant taxa, the marker tested was not further used on any other species.

Another marker, the intron of nad 7 gene, encoding the subunit 7 of NADH dehydrogenase complex I, was amplified by PCR with universal primers nad7/2 and nad 7/3 (Dumolin-Lapegue et al. 1997). After an initial denaturation at $94^{\circ} \mathrm{C}$ for $3 \mathrm{~min}$, conditions were as follows: 40 cycles of denaturation at $94^{\circ} \mathrm{C}$ for $45 \mathrm{~s}$, annealing at $50^{\circ} \mathrm{C}$ for $45 \mathrm{~s}$ and extension at $72^{\circ} \mathrm{C}$ for $1 \mathrm{~min}$. The final extension was at $72^{\circ} \mathrm{C}$ for $5 \mathrm{~min}$. A $25 \mu \mathrm{l}$ reaction mixture was used that contained $250 \mu \mathrm{M}$ dNTPs, $0.6 \mu \mathrm{M}$ of each primer, $1 \times \mathrm{PCR}$ buffer, $2 \mathrm{mM} \mathrm{MgCl} 2,5 \mu \mathrm{l}$ of template DNA (with a final concentration of about $10 \mathrm{ng}^{-1} \mathrm{l}^{-1}$ ) and $2.5 \mathrm{U}$ of Taq polymerase (Invitrogen).
Chloroplastidial regions: Three chloroplastidial regions were amplified (trnL, trnL-F and matK/trnK intron) (Table 2) (Taberlet et al. 1991, Johnson \& Soltis 1995) and one was analyzed by aligning the sequences available in GenBank ( $r b c \mathrm{~L}, \mathrm{U} 80718$ and U80719). As in the case of mtDNA, chloroplastidial markers were discarded when low levels of divergence were observed between the Mediterranean and Australian representatives. For all 4 markers we used a reaction mixture of $25 \mu \mathrm{l}$ containing $250 \mu \mathrm{M}$ dNTPs, $0.6 \mu \mathrm{M}$ of each primer, $1 \times$ PCR buffer, $2 \mathrm{mM} \mathrm{MgCl}_{2}, 5 \mu$ of template DNA (with a final concentration of about $10 \mathrm{ng}$ $\mu^{-1}$ ) and $2 \mathrm{U}$ of Taq polymerase.

The entire fragment of mat $\mathrm{K}$ region was amplified together with a significant portion of the flanking regions (trnK) using trnK-3914F (monocot) and trnK-2R universal primers (Johnson \& Soltis 1995). Due to unspecific amplifications, the expected bands (of approximately $2600 \mathrm{bp}$ ) corresponding to the trnK region were extracted from the gel and cloned using pGEM-T Easy 
vector. Sequences were then obtained using M13 primers and new specific primers (Table 2) were designed for Posidonia species on adjacent regions of the matK/trnK intron that were conserved in all species.

ITS region (nuclear marker): The complete ITS region of the nuclear ribosomal DNA (ITS1, 5.8S rDNA and ITS2) was amplified using the primers ITS1 and ITS4 (White et al. 1990) following the same conditions described in (Kumar \& Shukla 2005). The $25 \mu$ reaction mixture contained $100 \mu \mathrm{M}$ dNTPs, $0.5 \mu \mathrm{M}$ of each primer, $1 \times \mathrm{PCR}$ buffer, $1.5 \mathrm{mM} \mathrm{MgCl}_{2}, 5 \mu$ of template DNA (with a final concentration of about $10 \mathrm{ng}^{-1}$ ) and $1 \mathrm{U}$ of Taq polymerase.

All PCR amplifications were performed on a thermal cycler (GeneAmp PCR System 9700, Applied Biosystems) and all PCR products were cleaned with ExoSAP-IT Clean-Up enzyme (USB) following the manufacturer's protocol and then sequenced according to the Sanger method on a genetic analyzer (model ABI 3130xl, Applied Biosystems) using forward and reverse primers.

Alignment. For individual accessions, chromatograms were first imported and processed for quality with the PreGap4 program of the Staden Package (Staden 1996). Contiguous sequences were then assembled and consensus sequences obtained using the shotgun assembly option of the Gap4 program of the Staden Package. Finally, sequences were aligned using CLUSTAL X (Thompson et al. 1997) to detect polymorphisms and check for putative sequencing errors. One haplotype/genotype per species was chosen to reconstruct phylogenies, as the various individuals/sampling units sequenced per taxa did not show any polymorphism.

Phylogenetic data analysis. Phylogenetic analyses were performed on 3 molecular data sets: (1) ITS, (2) trnL and (3) trnL-F (concatenating sequences were amplified with primers $\mathrm{c}-\mathrm{d}$ and $\mathrm{e}-\mathrm{f}$ after the last one was too small to be analyzed by itself; see Table 2 for description of primers $\mathrm{c}-\mathrm{f}$ ) by means of the same methodology and an equal number of sequences from each taxa. All 8 taxa ( 7 Australian taxa plus the unique Mediterranean taxon) were included for all analyses except for the trnL-F sequences where only 6 species were amplified for one individual/species, due to consistent failure in the amplification of Posidonia denhartogii and $P$. australis. In the ITS analyses, Ruppia cirrhosa (AJ012292) was used as the outgroup, while $P$. oceanica was used for the trnL data set as the outgroup as the former was shown to decrease the phylogenetic resolution.

Maximum parsimony (MP) analyses were conducted with PAUP* v. 4.0 Beta Windows (Swofford 2002). MP searches were conducted using heuristic search methods with tree bisection reconnection (TBR) branch swapping, collapse of zero length branches and equal weighting of all characters. The analyses were repeated 1000 times with the 'random addition' option. To assess confidence in clades, bootstrap tests (Felsenstein 1985) were performed using 1000 replicates with heuristic search settings identical to those of the original search.

Maximum likelihood (ML) analyses were run on GARLI v. 0.96 (Zwickl 2006) and the best-suited nucleotide substitution model to be used on ML was determined by running Modeltest v. 3.7 (Posada \& Crandall 1998) on PAUP*. One single run with 10 search replicates was performed on GARLI. The number of generations without topology improvement required for termination was set to 20000 and the maximum score improvement over recent generations required for termination was set to 0.01 ; the remaining settings were kept at the default. Likelihood scores were obtained with PAUP*, as the implemented algo-

Table 2. Chloroplastic markers used in this study with respective primers and PCR parameters

\begin{tabular}{|c|c|c|c|}
\hline $\begin{array}{l}\text { Chloroplastic } \\
\text { markers }\end{array}$ & Primer $\left(5^{\prime}-3^{\prime}\right)$ & Source & PCR parameters \\
\hline $\operatorname{trn} \mathrm{L}-\mathrm{F}$ & $\begin{array}{l}\text { c: CGA AAT CGG TAG ACG CTA CG } \\
\text { d: GGG GAT AGA GGG ACT TGA AC } \\
\text { e: GGT TCA AGT CCC TCT ATC CC } \\
\text { f: ATT TGA ACT GGT GAC ACG AG }\end{array}$ & Taberlet et al. (1991) & $\begin{array}{l}94^{\circ} \mathrm{C}, 2 \mathrm{~min} ; 35 \times \\
\left(94^{\circ} \mathrm{C}, 1 \mathrm{~min} ; 53^{\circ} \mathrm{C}\right. \\
(\mathrm{c}, \mathrm{d}), 54^{\circ} \mathrm{C}(\mathrm{e}, \mathrm{f}) \\
\left.1 \mathrm{~min}^{\circ} 72^{\circ} \mathrm{C}, 2 \mathrm{~min}\right) \\
72^{\circ} \mathrm{C}, 7 \mathrm{~min}\end{array}$ \\
\hline $\begin{array}{l}\text { matK/ } \\
\text { trnK intron }\end{array}$ & $\begin{array}{l}\text { trnK-3914F: ATC TGG GTT GCT AAC TCA ATG G } \\
\text { trnK-2R: AAC TAG TCG GAT GGA GTA G }\end{array}$ & Johnson \& Soltis (1995) & $\begin{array}{l}94^{\circ} \mathrm{C}, 3 \mathrm{~min} ; 35 \times \\
\left(94^{\circ} \mathrm{C}, 1 \mathrm{~min} ; 53^{\circ} \mathrm{C},\right. \\
\left.1 \min ^{\circ} 72^{\circ} \mathrm{C}, 2 \mathrm{~min}\right)_{i} \\
72^{\circ} \mathrm{C}, 10 \mathrm{~min}\end{array}$ \\
\hline $\begin{array}{l}\text { matK/ } \\
\text { trnK intron2 }\end{array}$ & $\begin{array}{l}\text { PomatKFw: ACT GGA CTA TCT GTT TCG GTG GTA TCT } \\
\text { PomatKR: GCT TAC TAA TGG GAT ACC CGG ATA CAT }\end{array}$ & This study & $\begin{array}{l}94^{\circ} \mathrm{C}, 3 \mathrm{~min} ; 35 \times \\
\left(94^{\circ} \mathrm{C}, 1 \mathrm{~min}^{\circ} 60^{\circ} \mathrm{C},\right. \\
\left.1 \min ^{\circ} 72^{\circ} \mathrm{C}, 2 \mathrm{~min}\right) \\
72^{\circ} \mathrm{C}, 10 \mathrm{~min}\end{array}$ \\
\hline
\end{tabular}


rithm performs better for optimizing branch lengths on the final topology (Zwickl 2006). Supportive bootstrap values were calculated on GARLI and resulting trees were summarized in PAUP* .

Bayesian inference (BI) was performed in MrBayes v. 3.1.2 (Huelsenbeck \& Ronquist 2001). As some of the models given by Modeltest 3.7 are not accepted yet with MrBayes 3.1.2, the best nucleotide-substitution model was found by running MrModeltest 1.1b (Posada \& Crandall 1998, Nylander 2004) on PAUP*. Bayesian analyses were performed with 2 parallel Metropoliscoupled Markov chain (MCMC) runs of 1000000 generations, sampling trees every 100 generations, and 4 chains with the default heating. A Dirichlet distribution was used for the base frequency parameters. Burn-in was determined by inspection of the log-likelihoods of sampled trees and sample points collected prior to stationarity were eliminated from the sample. Convergence was confirmed by using AWTY (are we there yet?) graphical analysis (Nylander et al. 2008).

Divergence time estimation. Divergence times of the main splitting events within Posidonia were estimated with the Multidivtime program (Thorne et al. 1998, Kishino et al. 2001). We used the ML topology that was inferred using the ITS data set as starting phylogeny because phylogenetic relationships within the genus were better resolved. The methodology assumes autocorrelation of molecular rates among lineages (Kishino et al. 2001). This Bayesian method also requires the specification of prior distributions for parameters. The prior assumption for the mean and SD of the time of the ingroup root node ( $\mathrm{rttm}$ ) was set to 0.706 time units, and the mean of prior distribution for rate at root node (rtrate) was set at 0.138, where 1 time unit in this analysis represents $100 \mathrm{Myr}$. The SD of the prior distribution was set to its maximum value (equal to the mean) to avoid violation of the definition of a prior. The only reliable fossil of this genus corresponding to an early form of P. oceanica, which is from the Maastricht region, The Netherlands, and dated from the Cretaceous (70.6 to 65.5 Myr BP) (Den Hartog \& Kuo 2006, van der Ham et al. 2007), was used as calibration point. The MCMC method was employed to approximate both prior and posterior distributions (Kishino et al. 2001). Initial parameter values were randomly selected to initialize the Markov chain and then a burn-in period of 100000 cycles was completed before parameters were sampled from the MCMC. Afterwards, the state of the Markov chain was sampled every 100 cycles until a total of 10000 samples was collected.

Diversification rates through time. We investigated rates of diversification using the constant rate (CR) test with the $\gamma$ statistic (Pybus \& Harvey 2000, Pybus \& Rambaut 2002) as implemented in the $R$ package LASER v.2.3 (Rabosky 2006a,b). Because we have complete species sampling for the genus, the CR test is appropriate without having to perform a Monte Carlo simulation to account for missing lineages. Under a pure birth process (constant rates) $\gamma$-values follow a standard normal distribution with a mean of 0 (Pybus \& Harvey 2000). Negative $\gamma$ values suggest a slowdown in the rate of diversification through time whereas positive values indicate an increase in diversification rates towards the present. Therefore, the null hypothesis of constant rates is rejected at the $5 \%$ level in a 1 -tailed test if $\gamma<-1.645$ (Barraclough \& Vogler 2002). We also analyzed the semilogarithmic lineage through time (LTT) plot to evaluate whether the number of lineages was consistent with a constant rate of diversification through time. The relative cladogenesis statistics implemented in End-Epi 1.0 (Rambaut et al. 1997) allowed examining rates of diversification across the Bayesian-inferred linearized tree to identify branches in Posidonia phylogeny that show higher rates than expected under a constant model.

\section{RESULTS}

\section{Phylogenetic analysis}

Mitochondrial markers

Percentages of divergence for the 3 markers tested were between 0 and $0.2 \%$ among all species including the Mediterranean-Australian comparison (Table 3, including GenBank information). Due to this lack of polymorphism, those markers were not used to reconstruct phylogeny of Posidonia species.

\section{Chloroplastidial markers}

For the trnL marker the highest divergence was observed comparing Posidonia oceanica with species from the $P$. australis complex. The other chloroplastidial markers showed less than $1 \%$ of maximum divergence between these species, which were geographically separated by tens of thousands of kilometers; thus, they were not used for phylogenetic analyses. The only exception was trnL-F, which showed a cleavage due to a $200 \mathrm{bp}$ deletion in $P$. oceanica compared with the remaining congeneric species. Yet, concatenated sequences of both trnL and trnL-F did not provide additional information compared with the trnL marker alone, and phylogenetic analysis will therefore only be reported for trnL sequences (Table 4). Summary statistics for the parsimony, maximum likelihood and Bayesian analyses of nuclear and chloroplastidial marker (trnL) are summarized in Table 4. 
The alignment, as well as the values of maximum divergence level (Table 3), suggests enough resolution to separate at least 3 different groups of species based on the trnL region, corresponding to the clusters deter- mined on the basis of morphology (both Australian complexes and Posidonia oceanica). Yet, limited or nonexistent resolution was observed when building the trees using the different methods (data not shown).

Table 3. Summary of statistics for each marker analyzed. The aligned sequence length is the size of the sequences after aligning and counting with the intersections; for trnF Posidonia oceanica is almost half of the remaining sequences with $225 \mathrm{bp}$

\begin{tabular}{|c|c|c|c|}
\hline Marker type & $\begin{array}{c}\text { GenBank accession } \\
\text { number }\end{array}$ & $\begin{array}{l}\text { Aligned sequence } \\
\text { length (bp) }\end{array}$ & $\begin{array}{l}\% \text { of maximum divergence } \\
\text { level between complexes or species }\end{array}$ \\
\hline $\begin{array}{l}\text { Mitochondrial } \\
\text { nad7 intron }\end{array}$ & $\begin{array}{c}\text { GQ927731 GQ927732 } \\
\text { GQ927733 GQ927734 } \\
\text { GQ927735 GQ927736 } \\
\text { GQ927737 GQ927738 } \\
\text { GQ92773 }\end{array}$ & 745 & Between all species, $0 \%$ \\
\hline $\mathrm{cob}$ & DQ859149 DQ859148 & 1020 & P. oceanica vs. P. australis, $0.1 \%$ \\
\hline Atp 1 & DQ859111 DQ859112 & 1053 & P. oceanica vs. P. australis, $0.2 \%$ \\
\hline $\begin{array}{l}\text { Chloroplastidial } \\
\quad r b c \mathrm{~L}\end{array}$ & U80719 U80718 & 1182 & P. oceanica vs. P. australis, $0.8 \%$ \\
\hline mat $\mathrm{K} / \operatorname{trnK}$ intron2 & GQ927728 GQ927729 & 1150 & P. oceanica vs. P. kirkmanii, $0.7 \%$ \\
\hline $\operatorname{trnL}$ & $\begin{array}{c}\text { GQ927746 GQ927747 } \\
\text { GQ927748 GQ927749 } \\
\text { GQ927750 GQ927751 } \\
\text { GQ927752 GQ927753 } \\
\text { GQ927754 }\end{array}$ & 619 & P. oceanica vs. $P$. australis complex, $6.5 \%^{\mathrm{a}}$ \\
\hline $\operatorname{trn} \mathrm{L}-\mathrm{F}$ & $\begin{array}{l}\text { GQ927740 GQ927741 } \\
\text { GQ927742 GQ927743 } \\
\text { GQ927744 GQ927745 }\end{array}$ & 436 & P. oceanica vs. P. sinuosa, $14.3 \%$ \\
\hline $\begin{array}{l}\text { Nuclear } \\
\text { ITS }\end{array}$ & $\begin{array}{l}\text { GQ927719 GQ927720 } \\
\text { GQ927721 GQ927722 } \\
\text { GQ927723 GQ927724 } \\
\text { GQ927725 GQ927726 } \\
\text { GQ927727 }\end{array}$ & 715 & P. oceanica vs. P. ostenfeldii complex, $21.3 \%^{\mathrm{a}}$ \\
\hline
\end{tabular}

Table 4. (a) Summary of maximum parsimony analyses. CI: consistency index; RI: retention index. (b) Summary of maximum likelihood analyses. For Bayesian analyses the models chosen were GTR / F81 (Felsenstein 1981) for ITS and trnL, respectively. GTR: general time reversible; L: likelihood
(a) Maximum parsimony
No. of variable characters
No. of parsimony-informative characters
$214 / 53$
$63 / 2$
CI (all characters)
CI (excluding invariant characters) RI
$0.9742 / 1.0000$
$0.9012 / 1.0000$
$0.9238 / 1.0000$
(b) Maximum likelihood
Model of sequence evolution
TrN (Tamura \& Nei 1993) / F81 (Felsenstein 1981)
$-\mathrm{Ln}(\mathrm{L})$
Base frequencies
$2196.71008 / 810.85175$
$A=0.249317, C=0.283401, G=0.237653, T=0.229629 /$
$A=0.320819, C=0.143566, G=0.130724, T=0.404891$
Rate matrix

$$
\begin{aligned}
(\mathrm{A}-\mathrm{C}) & =1.000000,(\mathrm{~A}-\mathrm{G})=3.43098,(\mathrm{~A}-\mathrm{T})=1.000000 \\
(\mathrm{C}-\mathrm{G}) & =1.000000,(\mathrm{C}-\mathrm{T})=1.79173,(\mathrm{G}-\mathrm{T})=1.000000 / \\
(\mathrm{A}-\mathrm{C}) & =1.000000,(\mathrm{~A}-\mathrm{G})=11.50114,(\mathrm{~A}-\mathrm{T})=1.000000 \\
(\mathrm{C}-\mathrm{G}) & =1.000000,(\mathrm{C}-\mathrm{T})=0.011513,(\mathrm{G}-\mathrm{T})=1.000000
\end{aligned}
$$


Most differences found on alignment of sequences were indeed linked to differences in sequence structure (indels), which are considered as single events and do not increase the level of resolution much.

\section{ITS region}

ITS trees obtained from the 3 different methods were in strong agreement (Fig. 1, parsimony tree not shown) regarding not only the topology but also the branch lengths and bootstrap/posterior probability values. The divergence of Australian species from the Mediterranean species is readily apparent with additionally strong values validating the separation between the 2 Australian complexes recognized taxonomically (Fig. 1). In ML analysis, however, the species belonging to the Posidonia ostenfeldii complex have no statistical support to be considered as distinct species (Fig. 1). These results are also corroborated by Bayesian inference. Within the $P$. australis complex, whatever the method used, there is a clear divergence of $P$. australis and $P$. angustifolia from $P$. sinuosa.

\section{Divergence time estimation}

The divergence time obtained with Multidivtime (Thorne et al. 1998, Kishino et al. 2001) between the 2 major clades (Mediterranean and Australian) was estimated to be $68.0(65.6 ; 70.5)$ Myr BP (Fig. 2). The estimated time of the most recent common ancestor of the 2 Australian complexes was estimated at 12.8 (6.9; 23.7) Myr BP, followed by a likely latter diversification of the Posidonia australis complex that establishes the separation of $P$. sinuosa from the 2 other Posidonia lineages at about $8.4(3.8,16.6)$ Myr BP.

\section{Diversification rates through time}

The LTT plot (not shown) showed a slight increase of the number of lineages towards the present, while the CR test indicated a nonsignificant $\gamma$ value $(\gamma=1.99)$. The relative cladogenesis statistic did not identify any lineages with significantly higher diversification rates than expected.

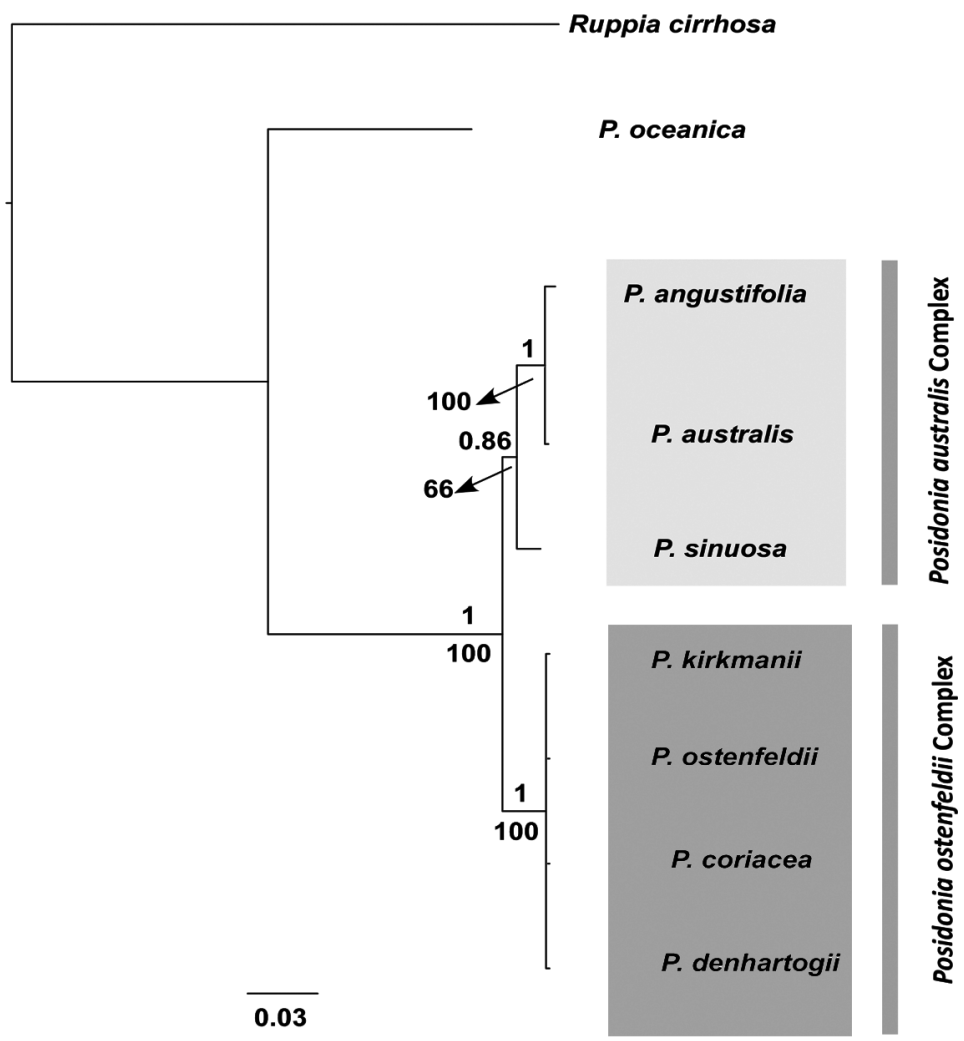

Fig. 1. Maximum likelihood $[-\ln (\mathrm{L})=2196.71008 / 2527.51495]$ and Bayesian tree of Posidoniaceae from the ITS data set. Numbers above branches represent posterior probabilities and numbers below branches represent nonparametric bootstrap proportion (greater than $50 \%$ )

\section{Alignment of ITS fragments of Posidonia oceanica from different Mediterranean regions}

Despite high polymorphism and genetic structure at microsatellites in Posidonia oceanica across the Mediterranean Sea (ArnaudHaond et al. 2007), none of the 40 ITS sequences from samples taken from Spain to Cyprus showed any difference for any of the $708 \mathrm{bp}$ that were sequenced and aligned.

\section{DISCUSSION}

\section{Phylogeny of Posidonia: ancient or recent species?}

The initial separation of the genus of Posidonia into Northern and Southern Hemisphere clusters, i.e. Mediterranean and Australian, is well supported by the ITS phylogeny. The first clade comprises a unique taxon, $P$. oceanica, that has been identified as the elder descendent of the Tethys Sea dweller P. cretacea (Larkum \& Den Hartog 1989). The novelty of our results is that our divergence time estimates suggest an early separation (>60 Myr BP) (Fig. 2), which would have occurred in the ancient Tethys Sea and at a relatively early stage during the origin of marine angio- 
sperms. This estimation is much older than the 16.7 Myr BP proposed by Les et al. (2003) using fixed substitution rates averaged from estimates obtained from distinct (nonseagrass) species and the 40 Myr BP suggested by Phillips \& Menez (1988) on the basis of geological and tectonic history. According to Les et al. (2003) the fixed substitution rate of $0.27 \%$ per Myr used in that study did not reflect the rate of ITS evolution in most taxa. Divergence time estimates based on biogeographic events might be not accurate if the selected vicariance event separated previously contiguous areas under a variety of processes (Zakharov et al. 2004) as occurred in the Tethys Sea. Those processes might include multiple events of separation and mixture of the considered area or gradual vicariances that occurred over a long time period. The Bayesian approach used in the present study is expected to yield more reliable estimates by incorporating a more consistent source of calibration (fossil record) and by accommodating possible rate variation across the tree.

The deep divergence between the single Mediterranean Posidonia oceanica and the several Australian Posidonia lineages may result from either (1) an accel- eration of diversification rates in some of the branches of the tree usually associated with recent adaptive radiations (Bromham \& Woolfit 2004) or (2) the existence of high background extinction rates. According to the relative cladogenesis statistics test, no ancestral branches exceeding the expected rates of lineage accumulation were identified in the Posidonia ultrametric tree. The CR test indicated a nonsignificant positive $\gamma$ value and did not support the hypothesis of a recent burst of cladogenesis. Therefore, the existence of high background extinction rates may more probably explain the deep divergence between $P$. oceanica and the Australian lineages. The estimate for the time when the the 2-antipode groups split matches the boundary for the mass extinction Cretaceous-Tertiary (K-T boundary) event. This catastrophic episode might have been responsible for a high number of extinctions of Posidonia ancestors, which explains the long branches separating Mediterranean and Australian clades in the reconstructed phylogenies. Stanley (2009) states that geographic range plays a role in survival from extinction at the genus level. Groups that have narrow geographic ranges or are ecologically

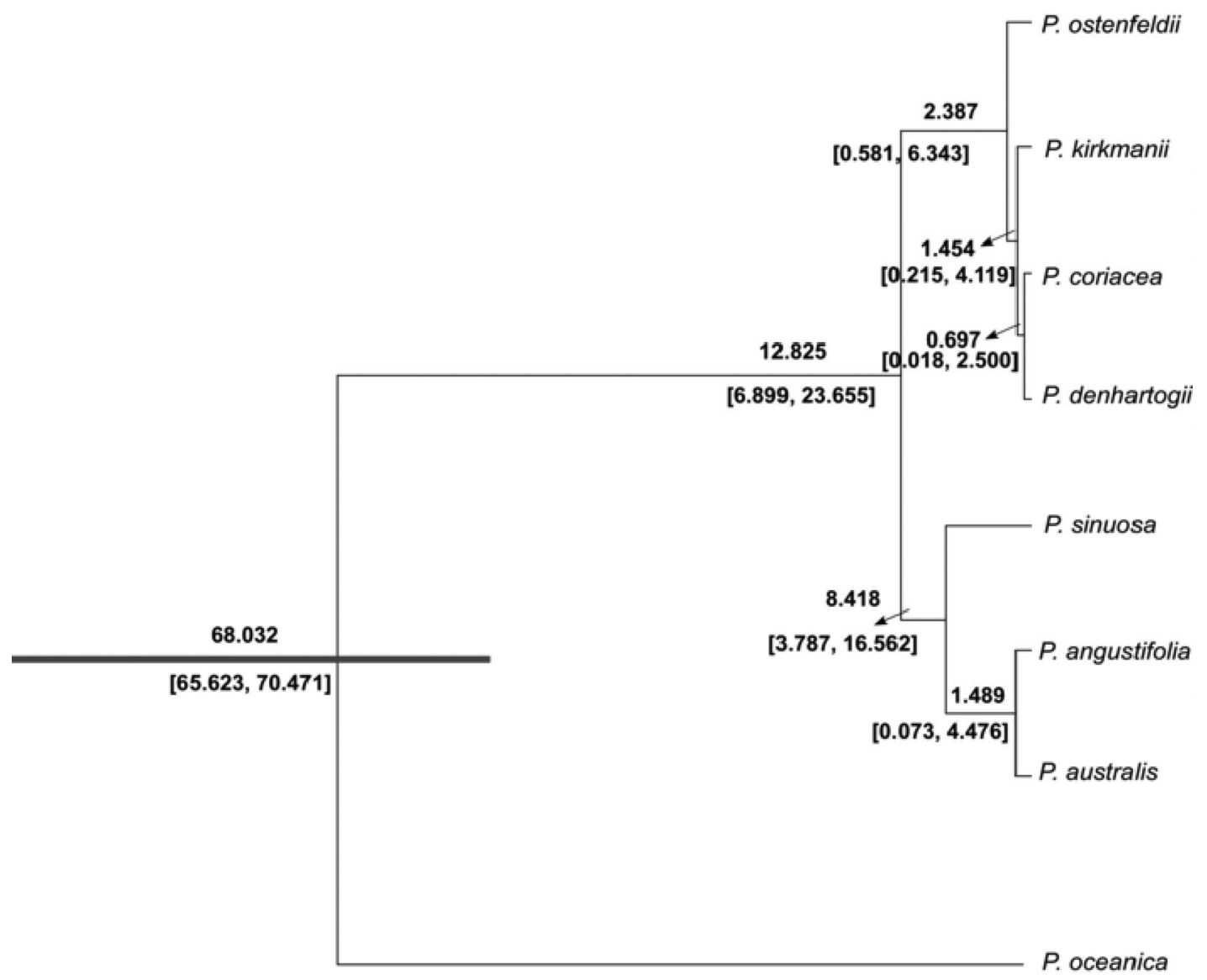

Fig. 2. Bayesian divergence dating analysis obtained with Multidivtime. Divergence dates were estimated on the ML topology derived from the ITS data set. Age estimates (in Myr, above branches) and corresponding $95 \%$ CI (bars and values in square brackets, below branches) are shown 
specialized tend to experience high background extinction rates (Stanley 2009). Mediterranean and Australian Posidonia species share a specific Mediterranean-like climate; therefore, ecological specialization may have driven the extinction of other members of this genus between these 2 disjunct regions.

Although the Mediterranean Sea has also experienced large environmental changes during its history (Bianchi \& Morri 2000), the only representative of the genus in the Northern Hemisphere is Posidonia oceanica. This scantiness of extant species may be due to the relatively homogeneous environment presently observed in the Mediterranean Sea in comparison to the southern Australian coasts, or to P. oceanica having been the only ancestral northern species that survived the recent major environmental changes in the Mediterranean Sea. However, some heterogeneity in the karyotypes of P. oceanica across various Mediterranean localities has been reported, with particular karyotypes being detected in one meadow of northern Africa (Algeria) (Semroud et al. 1992). Some phenological differences were also reported between eastern and western Mediterranean specimens (Bussotti et al. 1998). These observations led some investigators (Semroud et al. 1992, Bussotti et al. 1998) to question the taxonomic status of $P$. oceanica throughout the Mediterranean Sea. Biogeographic surveys of genetic diversity in $P$. oceanica (Arnaud-Haond et al. 2007, Serra et al. 2010), based on microsatellite nuclear markers, confirmed strong cleavage between populations in the eastern and western Mediterranean basins probably resulting from vicariance events during the last glaciations. Although such isolation maintained over appropriate time scales could lead to speciation, these population divergence patterns still do not support speciation (Arnaud-Haond et al. 2007, Serra et al. 2010). The results from the present phylogenetic analysis also support the existence of a single Mediterranean species, $P$. oceanica, as no polymorphism was observed for $708 \mathrm{bp}$ of the ITS throughout the entire Mediterranean Sea.

Posidonia oceanica species survived the closure and partial desiccation of the Mediterranean Sea during the Messinian salinity crisis (Boudouresque 2004) in putative Mediterranean refugial areas. Despite its long history a single sequence of ITS was recorded throughout the Mediterranean Sea, which suggests either (1) a loss of ancestral polymorphism levels during a population bottleneck that would be very specific to ITS as it strikingly contrasts with high diversity and population structure previously reported with microsatellite markers or (2) the retention of ancestral polymorphism as already reported for other organisms (Presa et al. 2002, Bower et al. 2008).

The second well-supported clade is composed of the Australian species of Posidonia. Speciation within the
Australian Posidonia has been suggested to have occurred during the Eocene (55.8 to 33.9 Myr BP), as a consequence of the separation of Australia from Antarctica (Kuo et al. 1990, Waycott et al. 1997). Such a hypothesis is not supported by the relaxed molecular clock analysis proposed here (Fig. 2), suggesting a much more recent estimation of speciation (no more than 23.7 Myr $\mathrm{BP})$. The results obtained show remarkable differences between the ITS sequence of both geographic groups of species-Mediterranean and Australian-compared with the small differences found among the Australian species. These differences support the hypothesis of a much more recent diversification of this genus in Australia that agrees with the divergence time estimate that places it around $12 \mathrm{Myr}$ ago (Fig. 2).

The morphological taxonomy of the Australian clade is only partially supported by the ITS and trnL marker (results not shown for the latter). The phylogenetic tree obtained differentiates with good support between the 2 complexes, Posidonia australis and P. ostenfeldii, which diverged from each other early in the history of Australian Posidonia taxa. This divergence is possibly correlated with the broad habitat differences experienced by both groups of species along the Australian coasts, where the $P$. australis complex is usually found associated with sheltered waters, and the $P$. ostenfeldii complex is found in open ocean environments and coastal sublittoral habitats that have high energy (Den Hartog \& Kuo 2006, Carruthers et al. 2007).

More recently in the phylogenetic tree, the analysis also supports the split of the Posidonia australis complex into 2 clades separating $P$. sinuosa from the remaining 2 taxa, $P$. australis and $P$. angustifolia, which are more closely related. However, the distinct species within the controversial $P$. ostenfeldii complex are not statistically supported ( $0 \%$ divergence). We are therefore left with 2 hypotheses about these taxa: (1) either those entities are synonymous and the morphological differences might express phenotypic plasticity in response to different environmental pressures along their distinct distributional ranges, or (2) the differentiation process started recently and may be still ongoing, in which case the lineage sorting has not yet been achieved, thereby preventing us from discriminating between those protospecies with the multiple genes sequenced here. Strong phenotypic plasticity has been demonstrated by confirming, by means of ITS sequences and microsatellites, the genetic identity of distinct morphotypes of the seagrass Zostera marina, which previously has been considered in some studies to be a distinct species (Becheler et al. 2010). We suggest that difficult morphological identification and unresolved ITS polymorphism support the hypothesis that the P. ostenfeldii complex would be composed of different morphotypes or ecotypes of the same species. 


\section{Slow evolution of mitochondrial markers in Posidonia}

Most phylogenetic studies on plants, clonal plants in particular, report only positive results, i.e. those obtained with markers with enough discriminatory power to allow phylogenetic reconstruction. This results in a paucity of information on negative results using fewer polymorphic markers thus generating a deficit of discussion on the discrepancies in the evolution of distinct genes.

Relative to the nuclear and chloroplast genomes, mitochondrial variation was strikingly low given how long ago the divergence occurred as revealed by the nuclear genome. A complete lack of mitochondrial variation across $745 \mathrm{bp}$ of a noncoding sequence and extremely low variation across $2073 \mathrm{bp}$ of a coding region, even when comparing the Mediterranean Posidonia oceanica and the remaining Australian species, which diverged tens of millions of years ago, is perplexing.

The 3 different genomes of plants (nuclear, mitochondrial and chloroplastidial) evolve at remarkably different rates in most plant species (Wolfe et al. 1987, Palmer \& Herbon 1988). When looking at synonymous substitution rates, which should not be subject to selective forces, chloroplastidial DNA (cpDNA) evolves at only half the rate of nuclear DNA (nDNA), but about 3 times faster than mtDNA (results not shown). These relative rates are maintained across the 3 genomes in most plants studied (Muse 2000). Accordingly, mtDNA markers have typically been considered not variable enough to resolve small-scale phylogenetic patterns in plants.

Despite the well-documented slow evolution of mtDNA, an almost total absence of polymorphism between species that had separated during the closure of the Tethys Sea is puzzling, and even more so given the few mitochondrial mutations (nad7 marker) found between the distinct genera Posidonia and Cymodocea (GenBank accession no. GQ927730) showing divergence of only $4.1 \%$ (results not shown). The mitochondrial region is remarkably less divergent than the 2 other genomes, even when comparing the ratios for other plant species already known to have slow evolving mitochondrial genomes (Wolfe et al. 1987).

Plant mtDNA is much larger than animal mtDNA (15 to $18 \mathrm{~kb}$ ); even the smallest plant mitochondrial genome has more than $200 \mathrm{~kb}$, with maximum sizes up to $2400 \mathrm{kbp}$ (Palmer \& Herbon 1988). In contrast with animal mitochondrial genomes, most of the plant mitochondrial genome appears to be noncoding (Lynch et al. 2006) and therefore may be expected to evolve faster than in animals, yet this has only been observed in rare exceptions (Cho et al. 2004, Parkinson et al.
2005). Several explanations for the apparent slow rate of evolution of plant mitochondria include (1) an efficient system of DNA repair and (2) a consequence of the long generation time of plants (Palmer \& Herbon 1988, Hellberg 2006, Nabholz et al. 2008), which is only expected to apply if generation time is inversely correlated with germ-line cell divisions as in most animals (Whittle \& Johnston 2003) but not necessarily in plants. Any demographic effects on mitochondrial mutation rate are expected to affect chloroplast mutation rates in the same way; therefore, the extreme difference between mitochondrial mutation and chloroplast rates in Posidonia suggest the occurrence of a mechanism specific to the mitochondrial genome, such as an efficient DNA repair system. A variety of different eukaryotes have developed highly efficient repair systems (France et al. 1996, van Oppen et al. 1999, Chen et al. 2000, Shearer et al. 2002, Duran et al. 2004, Tseng et al. 2005, Worheide 2006), whereas rare cases of plants with a high rate of nucleotide substitution in mitochondria (Cho et al. 2004, Parkinson et al. 2005) have been interpreted as the result of the loss of repair systems, e.g. key changes in the production and/or detoxification of oxygen free-radicals (Cho et al. 2004).

Considering that the divergence occurred 40 Myr BP as proposed by Phillips \& Menez (1988), which lies in the lower interval estimates obtained in our analysis, the estimated ITS mutation rates $(0.002$ substitutions site $^{-1} \mathrm{Myr}^{-1}$ ) fall into the values reported for ITS in woody plants (Kay et al. 2006) but are much lower than the other herbaceous species reported in this review. Higher values were also estimated for other marine macrophytes (e.g. Fucus vesiculosus) with a Northern/ Southern Hemisphere disjunct distribution, where ITS divergence between taxa from both hemispheres was of 37 to $45 \%$ (compared with the 20.8 to $21.3 \%$ obtained here for Posidonia) for a later separation time estimated in the Oligocene/Miocene, ca. 38 to $7 \mathrm{Myr}$ BP (Serrao et al. 1999). This indicates that either (1) besides specific mechanisms for mtDNA, some general factors cause slow DNA evolutionary rates in this genus and possibly in more seagrass species or (2) the separation between the Northern and Southern Hemisphere species may have occurred later in history as suggested by Les et al. (2003). This latter hypothesis would agree with the paleo-oceanographic history and the closure of Tethys Sea during the Miocene (20 to $10 \mathrm{Myr} \mathrm{BP}$ ) that left those 2 zones isolated (Searle et al. 1987, Robertson \& Comas 1998). Yet, P. oceanica, being a temperate taxon, may have been less affected by the closure of the Tethys Sea than were tropical species. Our results indicate that the separation of these 2 major groups was much more ancient, which therefore supports a slow evolutionary rate in the Posidonia genera. 
The clonality and the extreme generation time of seagrass species (e.g. Reusch et al. 1999, Alberto et al. 2001) may contribute to the slow nuclear genome evolution and the lack of mitochondrial variation reported here, although other mechanism such as DNA repair may also play a role in mtDNA evolution. Seagrasses originated in the Cretaceous 100 Myr BP (Larkum \& Den Hartog 1989, Klap et al. 2000) and comprise only a few dozen species throughout the world, demonstrating exceedingly low speciation rates. The most common explanations for such low number of taxa are (1) the absence of animal pollinators, which has removed coevolutionary relationships with pollinators as drivers of speciation, as typically observed in terrestrial systems (van der Hage 1996, Ollerton \& McCollin 1998, Raven 1998), and (2) the lack of barriers to gene flow in the marine environment (Hemminga \& Duarte 2000, Darling et al. 2004). This last hypothesis has been contradicted by evidence of common genetic differentiation among seagrass meadows even across short distances (Coyer et al. 2004, Olsen et al. 2004, ArnaudHaond et al. 2007, Alberto et al. 2008, Becheler et al. 2010). Although the absence of coevolution with pollinators cannot be discarded as an influencing factor, the results derived here also suggest that slow evolutionary rates may account for the poor speciation in seagrasses. Longer generation time in plants is associated with slower evolutionary rates (Charlesworth \& Wright 2001, Nabholz et al. 2008) and clonal growth may extend the generation time by seriously lowering the frequency of meiotic events.

In summary, the results presented here, using a range of markers, confirm the differentiation between Australian and Mediterranean Posidonia as well as the existence of 2 clades of Posidonia species in the Australian flora. However, only 4 lineages can be discriminated out of the 7 morphotypes sampled in Australia, suggesting either a high phenotypic plasticity as reported for other seagrass species or an extremely recent diversification. The DNA evolutionary rates found also appear to be among the slowest reported for herbaceous plants, in particular for mtDNA. Those differences in evolutionary rates could possibly be due to the clonal nature, slow growth and extended generation times in the genus Posidonia, which agrees with reported slow speciation rates among seagrass species and a possible specific mtDNA repair mechanism similar to the one described in some clonal cnidarians (Tseng et al. 2005).

Acknowledgements. We thank the anonymous reviewers for their comments and advice. This work was supported by a doctoral fellowship awarded to T.A. (SFRH/BD/30043/2006) and the projects DIVSTAB (POCI/MAR/60179/2004) and IBISA (PTDC/MAR/64749/2006) from the Portuguese Foundation for Science and Technology (FCT), FEDER and FSE. Fieldwork in
Australia was supported by a Fisheries Research and Development Corporation grant (FRDC 2001/060) and an ARC Discovery grant to G.A.K.

\section{LITERATURE CITED}

Alberto F, Mata L, Santos R (2001) Genetic homogeneity in the seagrass Cymodocea nodosa at its northern Atlantic limit revealed through RAPD. Mar Ecol Prog Ser 221:299-301

Alberto F, Massa S, Manent P, Diaz-Almela E, Arnaud-Haond S, Duarte CM, Serrao EA (2008) Genetic differentiation and secondary contact zone in the seagrass Cymodocea nodosa across the Mediterranean-Atlantic transition region. J Biogeogr 35:1279-1294

> Arnaud-Haond S, Migliaccio M, Diaz-Almela E, Teixeira S and others (2007) Vicariance patterns in the Mediterranean Sea: east-west cleavage and low dispersal in the endemic seagrass Posidonia oceanica. J Biogeogr 34: 963-976

Barraclough TG, Vogler AP (2002) Recent diversification rates in North American tiger beetles estimated from a dated mtDNA phylogenetic tree. Mol Biol Evol 19:1706-1716

Becheler R, Diekmann OE, Hily C, Moalic Y, Arnaud-Haond S (2010) The concept of population in clonal organisms: mosaics of temporally colonized patches are forming highly diverse meadows of Zostera marina in Brittany. Mol Ecol 19:2394-2407

Bianchi CN, Morri C (2000) Marine biodiversity of the Mediterranean Sea: situation, problems and prospects for future research. Mar Pollut Bull 40:367-376

Boudouresque CF (2004) Marine biodiversity in the Mediterranean: status of species, populations and communities. Sci Rep Port-Cros Natl Park Fr 20:97-146

Bower JE, Dowton M, Cooper RD, Beebe NW (2008) Intraspecific concerted evolution of the rDNA ITS1 in Anopheles farauti sensu stricto (Diptera: Culicidae) reveals recent patterns of population structure. J Mol Evol 67:397-411

> Bromham L, Woolfit M (2004) Explosive radiations and the reliability of molecular clocks: island endemic radiations as a test case. Syst Biol 53:758-766

Bussotti S, Guidetti P, Matricardi G (1998) Morphological analysis of Posidonia oceanica flowers from a reef formation and a shallow water meadow of the Ligurian Sea (north-western Mediterranean). Vie Milieu 48:55-62

Cambridge ML, Kuo J (1979) Two new species of seagrasses from Australia, Posidonia sinuosa and P. angustifolia (Posidoniaceae). Aquat Bot 6:307-328

Campey ML, Waycott M, Kendrick GA (2000) Re-evaluating species boundaries among members of the Posidonia ostenfeldii species complex (Posidoniaceae) - morphological and genetic variation. Aquat Bot 66:41-56

Carruthers TJB, Dennison WC, Kendrick GA, Waycott M, Walker DI, Cambridge ML (2007) Seagrasses of southwest Australia: a conceptual synthesis of the world's most diverse and extensive seagrass meadows. J Exp Mar Biol Ecol 350:21-45

Charlesworth D, Wright SI (2001) Breeding systems and genome evolution. Curr Opin Genet Dev 11:685-690

Chen CA, Wallace GC, Yu JK, Wei NV (2000) Strategies for amplification by polymerase chain reaction of the complete sequence of the gene encoding nuclear large subunit ribosomal RNA in corals. Mar Biotechnol 2:558-570

> Cho Y, Mower JP, Qiu YL, Palmer JD (2004) Mitochondrial substitution rates are extraordinarily elevated and variable in a genus of flowering plants. Proc Natl Acad Sci USA 101:17741-17746 
Cook CDK (1990) Aquatic plant book. SPB Academic Publishing, The Hague

Coyer JA, Diekmann OE, Serrao EA, Procaccini G and others (2004) Population genetics of dwarf eelgrass Zostera nolti throughout its biogeographic range. Mar Ecol Prog Ser 281:51-62

Cronquist A (1988) The evolution and classification of flowering plants, 2nd edn. The New York Botanical Garden, Bronx, NY

Darling KF, Kucera M, Pudsey CJ, Wade CM (2004) Molecular evidence links cryptic diversification in polar planktonic protists to quaternary climate dynamics. Proc Natl Acad Sci USA 101:7657-7662

Den Hartog C (1970) Seagrasses of the world. North-Holland Publishing, Amsterdam

Den Hartog C, Kuo J (2006) Taxonomy and biogeography of seagrasses. In: Larkum AWD, Orth RJ, Duarte C (eds) Seagrasses: biology, ecology and conservation. Springer, Dordrecht, p 1-23

Doyle JJ, Doyle JL (1987) A rapid DNA isolation procedure for small quantities of fresh leaf tissue. Phytochem Bull 19: 11-15

> Dumolin-Lapegue S, Pemonge MH, Petit RJ (1997) An enlarged set of consensus primers for the study of organelle DNA in plants. Mol Ecol 6:393-397

Duran S, Pascual M, Turon X (2004) Low levels of genetic variation in mtDNA sequences over the western Mediterranean and Atlantic range of the sponge Crambe crambe (Poecilosclerida). Mar Biol 144:31-35

Felsenstein J (1981) Evolutionary trees from DNA-sequences: a maximum-likelihood approach. J Mol Evol 17:368-376

$>$ Felsenstein J (1985) Confidence limits on phylogenies: an approach using the bootstrap. Evolution 39:783-791

France SC, Rosel PE, Agenbroad JE, Mullineaux LS, Kocher TD (1996) DNA sequence variation of mitochondrial largesubunit rRNA provides support for a two-subclass organization of the Anthozoa (Cnidaria). Mol Mar Biol Biotechnol 5:15-28

Gobert S, Cambridge ML, Velimirov B, Pergent G and others (2006) Biology of Posidonia. In: Larkum AWD, Orth RJ, Duarte C (eds) Seagrasses: biology, ecology and conservation. Springer, Dordrecht, p 387-408

Hellberg ME (2006) No variation and low synonymous substitution rates in coral mtDNA despite high nuclear variation. BMC Evol Biol 6: 24

Hemminga MA, Duarte CM (2000) Seagrass ecology. Cambridge University Press, Cambridge

Hooker J, Thomson T (1858) Præcursores ad floram indicam. J Proc Linn Soc Lond (Botany) 2:1-29, 54-103, 163-80

Huelsenbeck JP, Ronquist F (2001) MRBAYES: Bayesian inference of phylogenetic trees. Bioinformatics 17:754-755

Johnson LA, Soltis DE (1995) Phylogenetic inference in Saxifragaceae sensu-stricto and Gilia (Polemoniaceae) using MatK sequences. Ann Mo Bot Gard 82:149-175

Kay KM, Whittall JB, Hodges SA (2006) A survey of nuclear ribosomal internal transcribed spacer substitution rates across angiosperms: an approximate molecular clock with life history effects. BMC Evol Biol 6:36

Kishino H, Thorne JL, Bruno WJ (2001) Performance of a divergence time estimation method under a probabilistic model of rate evolution. Mol Biol Evol 18:352-361

Klap VA, Hemminga MA, Boon JJ (2000) Retention of lignin in seagrasses: angiosperms that returned to the sea. Mar Ecol Prog Ser 194:1-11

Kumar M, Shukla PK (2005) Use of PCR targeting of internal transcribed spacer regions and single-stranded conformation polymorphism analysis of sequence variation in dif- ferent regions of rRNA genes in fungi for rapid diagnosis of mycotic keratitis. J Clin Microbiol 43:662-668

Kuo J, Cambridge ML (1984) A taxonomic study of the Posidonia ostenfeldii complex (Posidoniaceae) with description of four new Australian seagrasses. Aquat Bot 20:267-295

Kuo J, James SH, Kirkman H, Denhartog C (1990) Chromosome numbers and their systematic implications in Australian marine angiosperms: the Posidoniaceae. Plant Syst Evol 171:199-204

Larkum AWD, Den Hartog CV (1989) Evolution and biogeography of seagrasses. In: Larkum AWD, McComb AJ, Shepherd SA (eds) Biology of seagrasses: a treatise on the biology of seagrasses with special reference to the Australian region. Elsevier, Amsterdam, p 112-156

$>$ Les DH, Cleland MA, Waycott M (1997) Phylogenetic studies in Alismatidae, II: evolution of marine angiosperms (seagrasses) and hydrophily. Syst Bot 22:443-463

Les DH, Crawford DJ, Kimball RT, Moody ML, Landolt E (2003) Biogeography of discontinuously distributed hydrophytes: a molecular appraisal of intercontinental disjunctions. Int J Plant Sci 164:917-932

Losos JB (2000) Ecological character displacement and the study of adaptation. Proc Natl Acad Sci USA 97: 5693-5695

Lynch M, Koskella B, Schaack S (2006) Mutation pressure and the evolution of organelle genomic architecture. Science 311:1727-1730

> Muse SV (2000) Examining rates and patterns of nucleotide substitution in plants. Plant Mol Biol 42:25-43

Nabholz B, Glémin S, Galtier N (2008) Strong variations of mitochondrial mutation rate across mammals-the longevity hypothesis. Mol Biol Evol 25:120-130

Nylander JAA (2004) MrModeltest v2. Program distributed by the author. Evolutionary Biology Centre, Uppsala University, Uppsala

> Nylander JAA, Wilgenbusch JC, Warren DL, Swofford DL (2008) AWTY (are we there yet?): a system for graphical exploration of MCMC convergence in Bayesian phylogenetics. Bioinformatics 24:581-583

Ollerton J, McCollin D (1998) Insect and angiosperm diversity in marine environments: a response to van der Hage. Funct Ecol 12:976-977

Olsen JL, Stam WT, Coyer JA, Reusch TBH and others (2004) North Atlantic phylogeography and large-scale population differentiation of the seagrass Zostera marina L. Mol Ecol 13:1923-1941

Palmer JD, Herbon LA (1988) Plant mitochondrial DNA evolves rapidly in structure, but slowly in sequence. J Mol Evol 28:87-97

Palumbi SR (1994) Genetic divergence, reproductive isolation, and marine speciation. Ann Rev Ecol Syst 25:547-572

Parkinson CL, Mower JP, Qiu YL, Shirk AJ and others (2005) Multiple major increases and decreases in mitochondrial substitution rates in the plant family Geraniaceae. BMC Evol Biol 5:73

> Pasqualini V, Pergent-Martini C, Clabaut P, Pergent G (1998) Mapping of Posidonia oceanica using aerial photographs and side scan sonar: application off the Island of Corsica (France). Estuar Coast Shelf Sci 47:359-367

Phillips RC, Menez EG (1988) Seagrasses. Smithsonian Institution Press, Washington, DC

Posada D, Crandall KA (1998) MODELTEST: testing the model of DNA substitution. Bioinformatics 14:817-818

Presa P, Pardo BG, Martinez P, Bernatchez L (2002) Phylogeographic congruence between mtDNA and rDNA ITS markers in brown trout. Mol Biol Evol 19:2161-2175 
Pybus OG, Harvey PH (2000) Testing macro-evolutionary models using incomplete molecular phylogenies. Proc R Soc Biol Sci Ser B 267:2267-2272

Pybus OG, Rambaut A (2002) GENIE (genealogy interval explorer) version 3.0. Department of Zoology, University of Oxford, Oxford

Rabosky DL (2006a) LASER: a maximum likelihood toolkit for detecting temporal shifts in diversification rates from molecular phylogenies. Evol Bioinform Online 2:257-260

Rabosky DL (2006b) Likelihood methods for inferring temporal shifts in diversification rates. Evolution 60:1152-1164

Rambaut A, Harvey PH, Nee S (1997) End-Epi: an application for reconstructing phylogenetic and population processes from molecular sequences. Comput Appl Biosci 13: 303-306

Raven JA (1998) Insect and angiosperm diversity in marine environments: further comments on van der Hage. Funct Ecol 12:977-979

Reusch TBH, Bostrom C, Stam WT, Olsen JL (1999) An ancient eelgrass clone in the Baltic. Mar Ecol Prog Ser 183:301-304

Robertson A, Comas M (1998) Collision-related processes in the Mediterranean region-introduction. Tectonophysics 298:1-4

Searle MP, Windley BF, Coward MP, Cooper DJW and others (1987) The closing of Tethys and the tectonics of the Himalaya. Geol Soc Am Bull 98:678-701

Semroud R, Verlaque R, Crouzet A, Boudouresque CF (1992) On a broad-leaved form of the seagrass Posidonia oceanica (Posidoniaceae) from Algiers (Algeria). Aquat Bot 43: 181-198

Serra IA, Innocenti AM, Di Maida G, Calvo S and others (2010) Genetic structure in the Mediterranean seagrass Posidonia oceanica: disentangling past vicariance events from contemporary patterns of gene flow. Mol Ecol 19: 557-568

Serrao EA, Brawley SH, Hedman J, Kautsky L, Samuelson G (1999) Reproductive success of Fucus vesiculosus (Phaeophyceae) in the Baltic Sea. J Phycol 35:254-269

Shearer TL, Van Oppen MJ, Romano SL, Wörheide G (2002) Slow mitochondrial DNA sequence evolution in the Anthozoa (Cnidaria). Mol Ecol 11:2475-2487

Spalding M, Taylor M, Ravilious C, Short F, Green E (2003) The distribution and status of seagrasses. In: Green EP, Short FT (eds) World atlas of seagrasses. University of California Press, Berkeley, CA

Staden R (1996) The Staden sequence analysis package. Mol Biotechnol 5:233-241

Stanley SM (2009) Evidence from ammonoids and conodonts for multiple early Triassic mass extinctions. Proc Natl Acad Sci USA 106:15264-15267

Swofford DL (2002) PAUP*. Phylogenetic analysis using parsimony ( ${ }^{*}$ and other methods). Sinauer Associates, Sunderland, MA

Taberlet P, Gielly L, Pautou G, Bouvet J (1991) Universal primers for amplification of three noncoding regions of chloroplast DNA. Plant Mol Biol 17:1105-1109

Tamura K, Nei M (1993) Estimation of the number of nucleotide substitutions in the control region of mitochondrial-DNA in humans and chimpanzees. Mol Biol Evol 10: $512-526$

Editorial responsibility: Philippe Borsa, Montpellier, France
Thompson JD, Gibson TJ, Plewniak F, Jeanmougin F, Higgins DG (1997) The CLUSTAL_X windows interface: flexible strategies for multiple sequence alignment aided by quality analysis tools. Nucleic Acids Res 25:4876-4882

> Thorne JL, Kishino H, Painter IS (1998) Estimating the rate of evolution of the rate of molecular evolution. Mol Biol Evol 15:1647-1657

Trautman DA, Borowitzka MA (1999) Distribution of the epiphytic organisms on Posidonia australis and P. sinuosa, two seagrasses with differing leaf morphology. Mar Ecol Prog Ser 179:215-229

Tseng CC, Wallace CC, Chen CA (2005) Mitogenomic analysis of Montipora cactus and Anacropora matthai (Cnidaria; Scleractinia; Acroporidae) indicates an unequal rate of mitochondrial evolution among Acroporidae corals. Coral Reefs 24:502-508

van der Ham R, van Konijnenburg-van Cittert JHA, Indeherberge L (2007) Seagrass foliage from the Maastrichtian type area (Maastrichtian, Danian, NE Belgium, SE Netherlands). Rev Palaeobot Palynol 144:301-321

> van Oppen MJH, Willis BL, Miller DJ (1999) Atypically low rate of cytochrome b evolution in the scleractinian coral genus Acropora. Proc R Soc Biol Sci Ser B 266:179-183

van der Hage JCH (1996) Why are there no insects and so few higher plants in the sea? New thoughts on an old problem. Funct Ecol 10:546-547

Vermeij G (1987) The dispersal barrier in the tropical Pacific: implications for molluscan speciation and extinction. Evolution 41:1046-1058

Waycott M, Les DH (2000) Current perspectives on marine angiosperm evolution. Biol Mar Mediterr 7:160-163

Waycott M, James SH, Walker DI (1997) Genetic variation within and between populations of Posidonia australis, a hydrophilous, clonal seagrass. Heredity 79:408-417

Waycott M, Procaccini G, Les DH, Reusch TBH (2006) Seagrass evolution, ecology and conservation: a genetic perspective. In: Larkum AWD, Orth RJ, Duarte C (eds) Seagrasses: biology, ecology and conservation. Springer, Dordrecht, p 25-50

White TJ, Bruns T, Lee S, Taylor J (1990) Amplification and direct sequencing of fungal ribosomal RNA genes for phylogenetics. Academic Press, San Diego, CA

Whittle CA, Johnston MO (2003) Broad-scale analysis contradicts the theory that generation time affects molecular evolutionary rates in plants. J Mol Evol 56:223-233

Wolfe KH, Li WH, Sharp PM (1987) Rates of nucleotide substitution vary greatly among plant mitochondrial, chloroplast, and nuclear DNAs. Proc Natl Acad Sci USA 84: 9054-9058

Worheide G (2006) Low variation in partial cytochrome oxidase subunit I (COI) mitochondrial sequences in the coralline demosponge Astrosclera willeyana across the Indo-Pacific. Mar Biol 148:907-912

- Zakharov EV, Caterino MS, Sperling FAH (2004) Molecular phylogeny, historical biogeography, and divergence time estimates for swallowtail butterflies of the genus Papilio (Lepidoptera: Papilionidae). Syst Biol 53:193

Zwickl DJ (2006) Genetic algorithm application for the phylogenetic analyses of large biological sequence datasets under maximum likelihood. PhD dissertation, University of Texas at Austin

Submitted: May 4, 2010; Accepted: October 15, 2010

Proofs received from author(s): December 20, 2010 